\title{
PARTICIPIAL SYSTEMS IN URALIC LANGUAGES: AN OVERVIEW
}

\author{
Ksenia Shagal \\ University of Helsinki
}

\begin{abstract}
This paper is an intragenetic typological study of participial systems in Uralic languages, a family demonstrating a significant degree of variation in this domain. The classification of participial forms is based primarily on two parameters, participial orientation, or relativizing capacity, and tense-aspect-modality (TAM). The sample comprises ten languages, and the data comes from descriptive studies as well as from native speakers and language experts. The study shows that participial systems in Uralic languages fall into three major groups, namely languages with inherently oriented participles, languages with contextually oriented participles, and languages featuring a combination of these participial types. The geographical distribution of participial systems shows strong areal tendencies resulting from language contact. For several centuries, western Uralic languages (e.g. Finnish and Hungarian) have been influenced by Slavic, Germanic and Baltic varieties, while eastern Uralic languages (e.g. Tundra Nenets and Khanty) historically form a linguistic area with northern Eurasian languages, such as Turkic and Yeniseian. As a result, the western varieties belong to the Standard Average European type with respect to participial properties, while the eastern ones make use of prenominal participial relative clauses, which are a well-known areal feature in North Asia. It is also noteworthy that Uralic languages do not show any clear matter borrowing in participial forms, so it is rather the pattern that is transmitted via contact.
\end{abstract}

Keywords: Uralic languages, participles, relative clauses, language contact, areal linguistics

DOI: https://doi.org/10.12697/jeful.2018.9.1.03

\section{Introduction}

This paper is an intragenetic typological study of participial systems focusing on the Uralic language family. Uralic languages are a perfect genealogical unit for a research of this kind, since their participial systems are very rich and well developed, and most members of the family make extensive use of participles in various subordinate structures. In addition, as I will show, Uralic languages demonstrate a very high degree of variation in their participial systems. 
In this study, participles are defined as non-finite verb forms that can be used for adnominal modification, cf. Shagal (2017: 1). The finiteness/ non-finiteness opposition is understood here as a binary distinction similar to that between balancing and deranking as introduced by Stassen (1985: 76-83) and further elaborated by van Lier (2009: 87). In other words, in order to be considered non-finite, a verb form has to exhibit certain morphosyntactic deviation from the prototypical predicate of an independent clause in a given language. This deviation can be manifested in restrictions imposed on verbal morphological categories or total loss thereof, acquisition of nominal morphological categories, or change in the encoding of various dependents.

For instance, Finnish - $m a$ forms traditionally referred to as agentive participles are one of the standard instruments that Finnish employs for direct object relativization (and direct object relativization only), as illustrated in (1a). The participle itself (laitta-ma-sta) does not have any finite tense or person/number markers, so the temporal interpretation of the participial relative clause can be fairly wide, cf. Shagal (2015). The agentive participant of the situation is expressed as a possessor, and in the example below bears a genitive marker (Maria- $n$ ). Finally, the participle obligatorily agrees in case and number with the modified noun (kalakuko-sta). Participial relative clauses are opposed to finite relative clauses, cf. (1b), where the verbal predicate appears in the same form as in independent sentences (laitt-oi), and it is able to take a nominative subject (Maria).

Finnish (Finnic, Finland, personal knowledge) ${ }^{1}$
a. pidä-n
[Maria-n laitta-ma-sta]
kalakuko-sta
like-NPST.1sG Maria-GEN prepare-PTCP.AG-ELA.Sg fish.pie-ELA.SG

'I like the fish pie made by Maria'

1 The borders of dependent clauses are indicated by square brackets throughout the paper, and the participles themselves are given in bold. When citing various printed sources, I generally keep the original glossing used by the authors (adapting it to follow the Leipzig glossing rules), especially in the cases where it reflects the classification of the form as a particular part of speech. Thus, forms that are regarded as participles for the purposes of this study can also be glossed as nominalizations or converbs, see Section 2 for more discussion on this matter. Whenever I refer to a participial marker in the text, I only use its most basic form, even if several morphophonological variants exist in the language. For instance, I refer to Finnish agentive participles as - $m a$ forms even though the marker changes to -mä after front vowels, e.g. syö-mä 'eaten (by someone)'. 
b. pidä-n kalakuko-sta, [jonka Maria laitt-oi]

like-NPST.1sG fish.pie-ELA.SG which.GEN.SG Maria prepare-PST.3sG

'I like the fish pie that Maria cooked'

For an initial illustration of the diversity, we can turn to Hill Mari, which provides examples of participles with a very different set of properties. For instance, forms in -šašlâk, unlike Finnish -ma participles, do not specialize in relativizing any particular participant. On the contrary, they are used in a wide variety of contexts including the relativization of locatives, as shown in (2). On the other hand, Hill Mari -ša ̌l $l \partial k$ participles have a limited time reference and are only used in future and debitive contexts. As opposed to regular independent clause predicates (e.g. stroj-en-äm), these forms do not take person/number markers. Nevertheless, they do allow both a genitive subject (Vas' $\ddot{a}-n)$, which can be regarded as a sign of nominalization, and a nominative subject $\left(\operatorname{Vas}^{\prime} \ddot{a}\right)$, which is rather a verbal property. According to the available data, participles in Hill Mari never agree with the modified noun in case and number, but Brykina and Aralova (2012) report that the agreement becomes obligatory in Meadow Mari if the participial relative clause occurs postnominally for certain communicative reasons, cf. (3).

(2) Hill Mari (Mari, Russia, personal field work)

\begin{tabular}{|c|c|c|c|c|}
\hline$\left[\operatorname{Vas}^{\prime} a(-n)\right.$ & älä-šäššlak ] & pört-ə̈m & $m \ddot{n} n^{\prime}$ & stroj-en-äm \\
\hline Vasya(-GEN) & live-PTCP.DEB & house-ACC & $1 \mathrm{SG}[\mathrm{NOM}]$ & build-PRF-1sG \\
\hline
\end{tabular}

'I built the house in which Vasya will live.'

(3) Meadow Mari (Mari, Russia, Brykina and Aralova 2012: 490)

memna-n čodara-šte, [ümbalne verlan-əš-əšte], šuko

1PL.OBL-GEN forest-INE On.INE be.located-PTCP.ACT-INE many

poygo ul-o

mushroom be-PRs.3sG

'In our forest, which is located farther away, there are a lot of mushrooms.'

The examples given above are already indicative of the substantial diversity that the Uralic language family exhibits on the level of individual forms. However, the differences appear to be even more significant if we compare not the participial forms as separate items, but 
rather the paradigms they form in particular languages. This second approach is precisely the focus of this article.

The sample used in the study comprises ten languages, at least one from each major traditionally recognized subgroup within the Uralic language family (cf. e.g. Salminen 2002), namely Tundra Nenets (Samoyedic), Hungarian and Khanty (Ugric), Komi-Zyryan and Udmurt (Permic), Hill Mari and Meadow Mari (Mari), Erzya (Mordvinic), North Saami (Saamic) and Finnish (Finnic). The data comes mainly from descriptive studies, but also from language consultants (Erzya, Hill Mari) ${ }^{2}$ and personal knowledge (Finnish).

The structure of the paper is as follows: Section 2 provides some basic information on the forms that can be classified as participles in Uralic languages. This includes some major functions of the forms in question, as well as the most important aspects of their internal and external syntax. In Section 3, I introduce two main typological parameters for the formation of participial paradigms in individual languages, namely participial orientation (Section 3.1) and TAM properties (Section 3.2). Different types of participial systems attested within the Uralic language family are described in Section 4. Sections 4.1, 4.2 and 4.3 present the Standard Average European type, the North Asian type and the mixed type respectively, while Section 4.4 is concerned with their distribution and the observed areal tendencies. While in Section 4 I only consider the paradigms of affirmative participles, Section 5 discusses the place of their negative counterparts within participial systems, in order to provide the whole picture. Finally, in Section 6, I summarize all the data and draw some conclusions.

2 The data and observations on participles in Erzya were discussed with native speakers during the field trip to the Dubyonki district (Mordovia, Russia) organized by the Helsinki Area and Language Studies (HALS) initiative in August 2013, as well as later in personal communication. The Hill Mari data presented in the article, which consists of elicited sentences (Russian to Mari translation) and grammaticality judgements, was collected on the field trip to the village of Mikryakovo (Mari El, Russia) in August 2017. The field trip was organized by the School of Linguistics of the National Research University Higher School of Economics, Moscow. 


\section{Functions and general properties of participles in Uralic languages}

Although the typological definition of participle adopted in this paper focuses on the adnominal function of non-finite forms, as illustrated in (1a) or (2), it is a well-known fact that Uralic non-finites can be very versatile in their functions. In particular, Uralic verbal paradigms tend to have no distinction between participles (adnominal modifiers) and action nominalizations (verbal arguments), compare the example (4a) from Komi-Zyryan, where the form vur-am is the predicate of a non-finite relative clause, to the example (4b), where exactly the same form heads a complement clause ${ }^{3}$ :

$$
\text { Komi-Zyryan, Pechora dialect (Permic, Russia, Serdobolskaya and }
$$
Paperno 2006: 1)

a. [mama-lis' vur-ęm] deręm me kos'al-i mother-GEN2 sew-PTCP shirt 1SG tear-PST

'I've torn the shirt mother sewed.'

b. [mama-lęn deręem vur-ẹm] menim kažitc'-e mother-GEN shirt sew-NMLZ 1SG.DAT like-PRs.3

'I like the way mother has sewn the shirt.'

In some (though relatively rare) cases, the form that is segmentally the same in both contexts can behave differently depending on the function. For example, in Hill Mari the possessive marker referring to the subject of the dependent clause (3rd person singular marker -žs in the examples below) attaches to the modified noun in case of relative clauses, cf. (5a), and to the nominalization itself in case of complement clauses, cf. $(5 b)^{4}$ :

3 Although the subject is encoded differently in the two examples (GEN2 and GEN), this difference is not related to the type of dependent clause in question. The second genitive is obligatorily used in Komi-Zyryan for encoding the subordinate clause subject when the head of the whole NP occupies the direct object position in the main clause, like 'the shirt' in 'I've torn the shirt', cf. Serdobol'skaja et al. (2012: 416).

4 There is also a tendency among the Hill Mari speakers to use a nominative subject in complement clauses, and a genitive subject in relative clauses, which can be regarded as a sign that the latter constructions are more nominalized, cf. Shagal and Volkova (to appear). 


$$
\text { Hill Mari (Mari, Russia, personal field work) }
$$

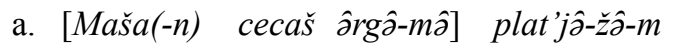
$u \check{z}-\hat{n} n-a t ?$ Masha-GEN now sew-NMLZ dress-POSS.3SG-ACC see-PRF-2SG

'Did you see the dress that Masha is sewing now?'

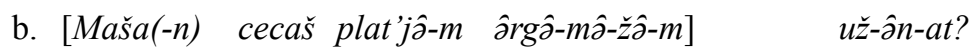
Masha-GEN now dress-ACC sew-NMLZ-POSS.3sG-ACC see-PRF-2SG

'Did you see that Masha is sewing a dress now?'

The participle/action nominalization polysemy illustrated above is a fairly widespread phenomenon cross-linguistically, see, for instance, Koptjevskaja-Tamm (1993: 42-44), Serdobolskaya and Paperno (2006), and Shibatani (2009). It can also be regarded as an areal feature in the languages of Siberia, since it is present not only in Uralic languages, but also in Mongolic, Turkic, Tungusic, Yeniseian, and some other language groups throughout northern Eurasia, cf. Nefedov (2012) and Pakendorf (2012).

Some of the Uralic languages possess non-finite forms whose multifunctionality is even wider. For example, the Tundra Nenets forms labelled as modal converbs by Nikolaeva (2014) can function as predicates of relative clauses, cf. (6a), complement clauses, cf. (6b), and adverbial clauses, cf. (6c):

(6) Tundra Nenets (Samoyedic, Russia, Nikolaeva 2014: 322, 354, 378)

a. [yil'e-s' $\left.{ }^{\circ}\right] \quad m^{\prime} a q-m^{\prime} i$

live-CVB.MOD tent-1sG

'the tent in which I live'

b. $\left[t i-m \quad \boldsymbol{x a d a}^{\circ}\right] \quad s^{\prime} i q t^{\circ} \quad$ tab'edas- $d^{\circ} m$

reindeer-ACC kill-CVB.MOD 2 SG.ACC order-1sG

'I forced/ordered you to kill the reindeer.'

c. $\left[\begin{array}{lll}\text { yarka } & \text { pee- } n^{\circ} h & \boldsymbol{t}^{\prime} \boldsymbol{e b o -}-^{\circ}\end{array}\right] \quad x^{\circ} \quad$ wabtarey $^{\circ}-q$ big stone-DAT bump.into-CVB.MOD sledge turn.over-REFL.3SG

'The sledge turned over after/because it bumped into a big stone.'

In addition to that, some of the Uralic participles can function as predicates of independent clauses as well. For instance, the Hill Mari form in $-m \hat{\partial}$, whose dependent use is exemplified in (5) above, can also 
function as a predicate of an independent sentence in resultative contexts where the agent cannot be specified, cf. $(7)^{5}$. The patientive participant of the situation can either take an accusative suffix or remain unmarked (in which case it looks like the nominative form). Importantly, in this case the $-m \hat{a}$ form still behaves as non-finite in that it does not take any verbal person/number or tense markers:

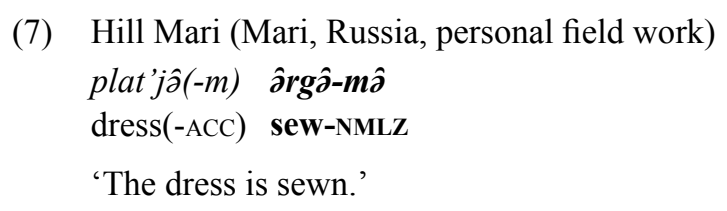

(7) Hill Mari (Mari, Russia, personal field work)

'The dress is sewn.'

One of the important signs of non-finiteness that participles exhibit in Uralic languages is the way of expressing the relative clause subject in cases of non-subject relativization ${ }^{6}$. Among the languages of the sample, Finnish, Erzya, North Saami and Tundra Nenets encode participial subjects as possessors using either genitive case marking, like Maria- $n$ in the Finnish sentence (1a), or possessive affixes, like - $m$ ' $i$ in the Tundra Nenets example (6a). The position of the possessive marker is different in different languages. In Finnish, for instance, it attaches to the participle itself, cf. (8), while in Tundra Nenets it normally appears on the head noun, and optionally also on the relative clause predicate, cf. (9):

(8) Finnish (Finnic, Finland, personal knowledge)
pidä- $n$
[laitta-ma-sta-si]
kalakuko-sta
like-NPST.1SG prepare-PTCP.AG-ELA.SG-POSS.2SG
fish.pie-ELA.SG

'I like the fish pie cooked by you'

(9) Tundra Nenets (Samoyedic, Russia, Nikolaeva 2014: 315)

[wol ${ }^{\circ}$ tampo- $\left.\underline{\boldsymbol{w e m t}}{ }^{\circ}\right] \quad$ xoba- $\underline{\boldsymbol{m} \boldsymbol{t}^{\circ}}$

dislike-PTCP.PFV.ACC.POSS.2SG skin-ACC.POSS.2SG

'the skin (ACC) that you disliked'

5 All the other participial forms in Hill Mari tend to be accompanied with an auxiliary when they occur in independent sentences, cf. Shagal and Volkova (to appear).

6 Peculiarities in direct object expression are much less common, both typologically and within the Uralic language family. Nevertheless, Hill Mari does exhibit variation in encoding the direct object in non-finite dependent clauses, while in independent sentences the direct object obligatorily bears an accusative case marker, cf. Toldova and Serdobol'skaja (2002). 
A typologically unusual feature of Uralic participles is that some of them require the subject of a relative clause to be expressed overtly. The - $m a$ form in Finnish, for instance, can only be derived from transitive verbs, and the A participant always has to be mentioned in the relative clause. Otherwise, the sentence is ungrammatical, cf. (10):

(10) Finnish (Finnic, Finland, personal knowledge)

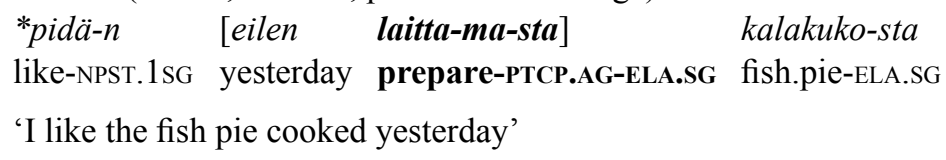

Erzya is slightly less strict in its requirements. In a relative clause introduced by the past participle in - $v t$, expressing the agentive participant is obligatory only if the participle has no other dependents, such as temporal adverbials, compare (11a) and (11b) below. Bartens (1999: 153 ) suggests that the nature of this restriction is purely morphological, since the form kizen' in Erzya is originally also a noun with a genitive case marker:

(11) Erzya (Mordvin, Russia, Bartens 1999: 153)
a. [*(t'et'a-n') rama-vt $]$ lišme-s'
father-GEN buy-PTCP.PST horse-DEF
'the horse bought by the father'

b. $\begin{array}{lll}\text { [kizen' } & \text { rama-vt }] & \text { skal } \\ \text { summer } & \text { buy-PTCP.PST } & \text { cow }\end{array}$

'the cow bought in summer'

Another way of expressing the subject in a participial relative clause is encoding it as a certain non-core participant. For example, Hungarian employs the postposition által, which is a strategy similar to that of many (Indo-)European languages, compare the Hungarian construction in (12) to its English translation:

(12) Hungarian (Ugric, Hungary, Kenesei et al. 1998: 46)

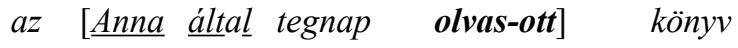

DEF Anna by yesterday read-PTCP.PST book

'the book read by Anna yesterday' 
The rest of the languages included in the sample feature several different ways of expressing the participial clause subject. For example, in Meadow Mari, which exhibits probably the most elaborate distribution, it can be expressed not only by a possessive suffix on the head noun or as a genitive participant, but also as a nominative or instrumental participant. The range of possibilities is different for personal pronouns, other pronouns, proper names, NPs denoting humans, NPs denoting other animate participants, and NPs denoting inanimate participants, as represented in Table 1 from Brykina and Aralova (2012: 488):

Table 1. Subject encoding in participial relative clauses in Meadow Mari

\begin{tabular}{l|c|c|c|c|c|c} 
& $\begin{array}{c}\text { Pers. } \\
\text { pron. }\end{array}$ & $\begin{array}{c}\text { Other } \\
\text { pron. }\end{array}$ & $\begin{array}{c}\text { Proper } \\
\text { name }\end{array}$ & $\begin{array}{c}\text { NP: } \\
\text { human }\end{array}$ & $\begin{array}{c}\text { NP: } \\
\text { anim. }\end{array}$ & $\begin{array}{c}\text { NP: } \\
\text { inan. }\end{array}$ \\
\hline POSS & + & - & - & - & - & - \\
\hline GEN & + & + & + & + & + & + \\
\hline NOM & - & - & - & $?$ & + & + \\
\hline INS (dene) & - & - & - & - & - & +
\end{tabular}

A very similar situation is attested in Komi-Zyryan, with a slightly wider range of options available for each type of participant, cf. Brykina and Aralova (2012: 503), and in the Beserman Udmurt relative clauses formed by $-m$ participles, cf. Brykina and Aralova (2012: 515). In Hill Mari, the overall tendency is basically the same as well: the higher the subject is on the Silverstein's (1976) animacy hierarchy, the more likely it is to be expressed as a possessor, that is, by a noun in genitive, a possessive marker on the modified noun or a combination thereof. However, according to my data, the subject of Hill Mari participial clauses is never encoded as a peripheral participant (either by a noncore case or by an adposition), so the nominative case is used for the least animate agents, such as natural forces (e.g. the wind or the sun) and inanimate objects (e.g. the socks or the books).

Finally, in Northern Khanty the agent in participial relative clauses takes either possessive or locative marking, cf. (13a) and (13b). According to Nikolaeva (1999: 76), the locative encoding of the agent signals that the relative clause is passive. There is, however, no data concerning when this passive strategy is used for relativization in the language. 
(13)

Northern Khanty (Ugric, Russia, Nikolaeva 1999: 78, 76)

a. [nay mo:smolt-o-m] o:xsa:r-e:n jel an man-l

$2 \mathrm{SG}$ wound-EP-PTCP.PST fox-POSS. $2 \mathrm{SG}$ far not go-NPST.3SG

'The fox you wounded will not go far.'

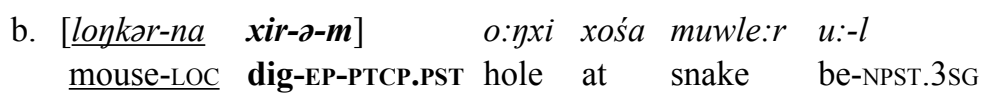

'In the hole dug by the mouse lives a snake.'

The properties considered in this section, namely the degree of multifunctionality exhibited by non-finite forms and the subject expression variation in participial relative clauses, differ greatly in the Uralic languages of the sample. However, within a particular language, these properties tend to be the same or at least very similar for all the participial forms. If, on the other hand, we are looking for the parameters that could serve as the basis for participial systems, we should look into the differences between individual forms within a language. The parameters of this kind are considered in the next section.

\section{Parameters for participial systems formation}

The three parameters that are crucial for distinguishing between different participial forms in Uralic languages are participial orientation, tense-aspect-modality (TAM), and polarity. The last one, however, is not relevant for all the languages, so it will be discussed separately in Section 5. The two following sections are concerned with the criteria that are the most common bases for participial paradigms cross-linguistically as well as within the Uralic family, namely participial orientation (Section 3.1) and TAM properties (Section 3.2).

\subsection{Orientation}

The notion of orientation was introduced to the typology of participles by Haspelmath (1994: 153) in order to describe different possible relations between the participle, which is a verb form, and the nominal it modifies, which is a participant of the verb to whose paradigm the participle belongs. The two main types of participles with respect to orientation are inherently oriented participles and contextually oriented participles, cf. Shagal (2017: 39-98). 
An inherently oriented participle is only able to relativize one particular participant of a certain verb. For example, active participles in Finnish can only relativize subjects of both transitive and intransitive verbs, cf. (14a) and (14b) respectively. Passive participles, on the other hand, specialize on the relativization of the participant that functions as a direct object in the corresponding active clause, cf. (14c). In rare cases, the orientation of passive participles can extend to certain noncore participants, cf. (14d) and Shagal (2017: 55), but such extensions should rather be treated as exceptions.

(14) Finnish (Finnic, Finland, personal knowledge)

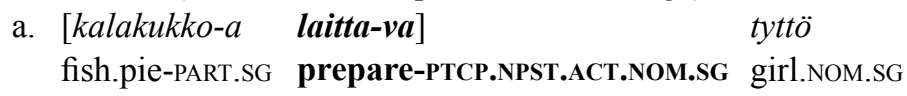
'the girl who is preparing a fish pie'

b. [hyvin nukku-nut] tyttö well sleep-PTCP.PST.ACT.NOM.SG girl.NOM.SG 'the girl who slept well'

c. [huomenna laite-ttava] kalakukko tomorrow prepare-PTCP.NPST.PASS.NOM.SG fish.pie.NOM.SG 'the fish pie that someone should prepare tomorrow'

d. [asu-ttu $]$ saari live-PTCP.PST.PASS.NOM.SG island.NOM.SG 'an inhabited island'

A single contextually oriented participle, on the other hand, can relativize a wide range of participants depending on the sentence it appears in. In the example below, one and the same Northern Khanty past participle in $-m$ relativizes a transitive subject, cf. (15a), a direct object, cf. (15b), an indirect object, cf. (15c), a peripheral participant whose interpretation may vary depending on a wider context, cf. (15d), and a possessor, cf. (15e):

(15) Northern Khanty (Ugric, Russia, Nikolaeva 1999: 76-77)

a. [luw-e:l we:l-o-m] ne:yxi

3SG-ACC kill-EP-PTCP.PST man

'the man who killed him' 
b. [luw jo:s-na u:s'-ə-m] mir-ə-l $3 \mathrm{SG}$ road-LOC meet-EP-PTCP.PST people-EP-POSS.3SG

'the people he met on the road'

c. $\left[\begin{array}{lll}\text { nay } & a: n & \mathbf{m i j}-\boldsymbol{-}-\boldsymbol{m}\end{array}\right] \quad$ pox-e:n e:walt $2 \mathrm{SG}$ cup give-EP-PTCP.PST boy-POSS.2SG about

'about the boy to whom you gave the cup'

d. $\left[a: s^{\prime} e:-m\right.$ potort-o-m $] \quad$ xatl father-1SG speak-EP-PTCP.PST day

'the day about which my father was speaking'/ 'the day when my father was speaking'

e. [n'a:wre:m-l-al wo:s-na man-o-m] purəs' ike:-ti child-PL-POSS. 3 city-LOC go-EP-PTCP.PST old man-PL 'the old men whose children went to the city'

The relativizing potential of Uralic contextually oriented participles in general tends to be fairly high. In particular, many of them are even able to relativize possessors, which are known to be among the most typologically difficult relativization goals, cf. Keenan and Comrie (1977). It is worth noticing, however, that this is the only type of participial relativization in Uralic languages where the role of the relativized participant is not simply assumed from the context, but is rather indicated in the relative clause by a resumptive element, for instance the possessive marker on the possessee, e.g. - al in the example (15e) from Northern Khanty.

\subsection{TAM properties}

Typologically, two main types of participial markers according to their TAM properties are the-TAM markers, which simply indicate the participial status of the form and do not themselves express any aspectual, temporal, or modal contrasts, and the +TAM markers, which do not only derive a participle from the verb stem, but also convey some information on the TAM meaning of the resulting form, cf. Shagal (2017: 119). Both types are attested in Uralic languages. 
An example of the-TAM participial marker is the marker -šs in Hill Mari. Depending on the context, it can refer to situations in the past, cf. (16a), present, cf. (16b), or future, cf. (16c):

Hill Mari (Mari, Russia, personal field work)

a. [tengečä zvoni-š̈̈] vrač tagačâ tokjô-m yesterday call-PTCP.ACT doctor today home-Poss.1sG

tol-ěs

come-NPST.3sG

'The doctor who called yesterday will come today.'

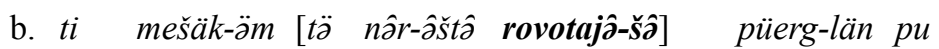
this bag-ACC that field-INE work-PTCP.ACT man-DAT give.IMP 'Give this bag to the man who is working in that field.'

c. [lem-z̈m kač-š̃ $]$ t'et'ä-vlä vele moroženâे-m soup-ACC eat-PTCP.ACT child-PL only ice.cream-ACC polučaj-a-t get-NPST.3-PL

'Only the kids who will have eaten the soup will get ice-cream.'

The participial markers belonging to the +TAM type can generally express absolute or relative tense, although in most cases it is hardly possible to draw a line between the two and formulate the exact TAM meaning of a particular participial form. The Hill Mari marker -šašlàk, for instance, is primarily used for future situations, cf. (2), but it sometimes also appears in debitive contexts. The so-called perfective and imperfective participles in Tundra Nenets differ in that the former typically refers to situations preceding those described in the main clause, while the latter is used when the two are simultaneous, compare (17a) and (17b):

(17) Tundra Nenets (Samoyedic, Russia, Nikolaeva 2014: 318)
a. [Moskva-xad $\left.\mathbf{t}^{\circ} \boldsymbol{\text { o-wi }}{ }^{\circ}\right]$

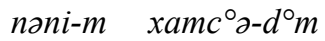 Moscow-ABL come-PTCP.PFV guy-ACC love-1sG

'I am in love with a guy who came from Moscow.' 
b. [Moskva-xəna yil'e-n'a $] \quad$ nəni-m $\quad x a m c^{\circ} \partial-d^{\circ} m$ Moscow-LOC live-PTCP.IPFV guy-ACC love-1SG

'I am in love with a guy who lives in Moscow.'

Some of the participles derived by markers that should rather be classified as -TAM do, however, have certain preferences regarding their temporal interpretation. In particular, temporal interpretation of a participial form can be conditional on some properties of the verb or the clause in general. For example, the Finnish participle in - $m a$ behaves differently depending on the aspectual class of the verb it is derived from, cf. Shagal (2015). In case there are no time adverbials in the relative clause, the situation is most likely to be interpreted as past for accomplishments, such as 'to read,' cf. (18a), and as present for states, such as 'to own', cf. (18b):

Finnish (Finnic, Finland, personal knowledge)
a. missä on
[luke-ma-si]
kirja?
where be.NPST.3sG read-PTCP.AG.NOM.SG-POss.2sG book.NOM.SG
'Where is the book you have read?'

b. [omista-ma-ni]

asunto on

own-PTCP.AG.NOM.SG-POSS.1sG apartment.NOM.SG be.NPST.3SG

$\begin{array}{lll}\text { suku-ni ensimmäinen koti } & \text { Helsingi-ssä } \\ \text { family.GEN.SG-POSs.1SG first.NOM.SG home.NOM.SG } & \text { Helsinki-INE.SG } \\ \text { 'The apartment that I own is the first home of my family in Helsinki.' }\end{array}$

Overall, the Uralic participles are able to express a fairly wide variety of TAM meanings including at least past, present and future tenses, perfective and imperfective aspect, potential and debitive modality. In addition, in Tundra Nenets, if a certain meaning cannot be expressed using the regular participial forms on their own, the language resorts to periphrastic constructions, e.g. the combination of a participle with a purposive converb, cf. Shagal (2017: 128). All these meanings, when intersecting with the different types of orientation, serve as a basis for participial systems as discussed in the following section. 


\section{Types of affirmative participial systems}

The paradigms of affirmative participles in Uralic languages are very diverse with respect to their size, i.e. the number of participial forms in a particular language, and the exact distinctions underlying the participial system. Nevertheless, three main types can be identified, which I will refer to as the Standard Average European type (Section 4.1), the North Asian type (Section 4.2), and the Mixed type (Section 4.3). After presenting all of the types, I will discuss their geographical distribution and show that they can be fruitfully investigated from an areal perspective (Section 4.4).

\subsection{Standard Average European type}

The participial systems of the first type consist entirely of participles inherently oriented towards certain core participants, i.e. A, $\mathrm{P}$ or $\mathrm{S}^{7}$. They are attested in the westernmost languages of the sample, namely North Saami, Finnish, Hungarian and Erzya, and they are overall common in the Standard Average European linguistic zone as described in Haspelmath (2001). This group, however, is not itself homogeneous, but rather contains two subtypes.

In Finnish and North Saami, the contrast in orientation is between active and passive participles, which relativize S/A and P participants respectively. North Saami features two active forms, past and present, cf. (19a), and one passive form, cf. (19b) ${ }^{8}$. A slightly more complicated Finnish system is presented in Table 2 below. Some of the non-Uralic languages whose participial system is based on a similar orientation contrast are Russian and Lithuanian.

7 Following Comrie (1981), I use the labels A, P and S to refer to the core participants of the clause. A stands for the subject of the transitive clause, P denotes the object of the transitive clause, and $\mathrm{S}$ is the label for the single participant of the intransitive clause.

8 According to Jussi Ylikoski (p.c.), many speakers of North Saami tend to use forms other than the passive participle in direct object relative clauses such as (19b). The speakers in Norway often use the past participle of the passive verb, e.g. ćállo(juvvo)t, while in Finland the regular past participle traditionally labelled as active (čállán) is common in this context. Therefore, for some of the North Saami speakers in Finland the past participle can relativize any of the core participants, which can be seen as a slight deviation from the strict active-passive system. 
(19) North Saami (Saamic, Finland, Ylikoski 2009: 132)
a. [reivve
čáll-i
/ čállá-n]
áhčči

letter.GEN/ACC write-PTCP.PRS / write-PTCP.PST father

'the father who is writing the letter / the father who wrote the letter'

b. [áhči čálli-n] reive

father.GEN/ACC write-PTCP.PASS.AG letter

'the letter written by the father'

Table 2. Affirmative participial system in Finnish

\begin{tabular}{l|c|c|c}
\multirow{2}{*}{} & \multirow{2}{*}{ S/A } & \multicolumn{2}{|c}{$\mathrm{P}$} \\
\cline { 3 - 3 } & & A not expressed & A expressed \\
\hline Present & $-v a$ & $-t a v a(+$ modal $)$ & $-m a$
\end{tabular}

In the languages of the second subtype, there is an inherently oriented participle which groups the core participants in a different way. It is a form that I refer to as absolutive participle, and it is able to relativize the $\mathrm{P}$ argument of a transitive verb and an $\mathrm{S}$ argument of an intransitive verb. An example of such participle is the Hungarian past participle in -ott, cf. (20a) and (20b). The absolutive participle in Hungarian is opposed to the active form illustrated in (20c):

(20) Hungarian (Ugric, Hungary, Kenesei et al. 1998: 45-47)

$\begin{array}{lllll}\text { a. az } & \text { [Anna által tegnap olvas-ott }] & \text { könyv } \\ \text { DEF Anna by yesterday } & \text { read-PTCP.PST } & \text { book }\end{array}$

'the book read by Anna yesterday'

b. a [tegnap London-ba érkez-ett $]$ lány DEF yesterday London-ILL arrive-PTCP.PST girl

'the girl that arrived to London yesterday'

c. a [könyv-et a fiú-nak gyorsan olvas-ó $]$ lány itt van. the book-ACC the boy-DAT fast read-PTCP.ACT girl here is 'The girl who reads the book to the boy fast is here.'

In Erzya, all the three types of inherently oriented participles are attested (the A/S-oriented participle in $-i\left(c^{\prime} a\right)$, the S/P-oriented parti- 
ciple in $-z^{\prime}$, and the P-oriented participle in $-v t$ ), as shown in Table 3. The passive participle in $-v t$ is, however, fairly marginal, so in this sense the Erzya paradigm appears closer to the Hungarian system.

Table 3. Participial system in Erzya

\begin{tabular}{l|c|c|c} 
& $\mathrm{A}$ & $\mathrm{S}$ & $\mathrm{P}$ \\
\hline Relative present & \multicolumn{2}{|c|}{$-i\left(c^{\prime} a\right)$} & \multicolumn{2}{|c}{$-z^{\prime}$} \\
\hline \multirow{2}{*}{ Relative past } & & \multicolumn{2}{|c}{$-v t$}
\end{tabular}

In Europe, participles that can be regarded as absolutive are attested at least in Italian, Albanian, Macedonian, and Modern Greek. In German, they co-exist with active participle Haspelmath (1994: 159-160), which brings the German system very close to the Hungarian one, see Moravcsik (1978), Kazenin (1994), and Aikhenvald and Dixon (2011), among others, on ergative patterns in otherwise accusative languages.

\subsection{North Asian type}

In the languages of the second type, Northern Khanty and Tundra Nenets, all the participial forms are contextually oriented. Northern Khanty exhibits the simplest system of this kind, with a non-past participle in $-t i$ and a past participle in $-m$. Both forms are able to relativize a great number of participants including not only the core participants of the situation, but also various adverbials and possessors.

Tundra Nenets has a more elaborate system with two distinct sets of forms used for relativization, see Table 4 . The forms belonging to the first set (referred to as participles by Nikolaeva 2014) can relativize all kinds of subjects and direct objects, while the others (action nominals and the modal converb) can relativize a wide range of peripheral participants, such as indirect objects, obliques, and diverse adverbials. The examples of relative clauses formed with participles were provided earlier in (9) and (17), the first one being an instance of direct object relativization, and the second one illustrating subject relativization. The examples below illustrate the use of other non-finites for the relativization of the indirect object, cf. (21a), the instrument, cf. (21b), the comitative adjunct, cf. (21c), and the time and locative adverbials, cf. (21d) and (21e) respectively: 
(21) Tundra Nenets (Samoyedic, Russia, Nikolaeva 2014: 321-325)

a. [kniga-m m'is-oqma(-m'i)] xasawa yac'ekem'i book-ACC give-PFV.NMLz-1sg man child.1sG

'the boy to whom I gave the book'

b. [yuda-m'i mada-qma(-m'i)] $x \partial r^{\circ}-m^{\prime} i$

hand-ACC.1SG cut-PFV.NMLZ-1sg knife-1sG

'the knife with which I cut my hand'

c. [yil'e-s'० / yil'es'ว-m'i] n'enес'ว-m'i

live-CVB.Mod / live.CVB.Mod-1sg person-1sG

'the person with whom I live'

d. $\left[\right.$ toxodano- $\left.^{\circ} \quad \boldsymbol{x} \overline{\boldsymbol{e}}-\mathbf{s}^{\circ}{ }^{\circ}\right] \quad$ yal'a-doh

study-CVB.MOD go-CVB.MOD day-3PL

'the day for them to go to study'

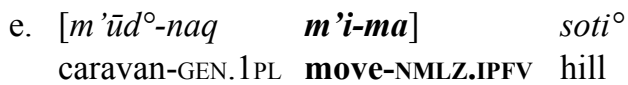

'the hill over which our caravan is moving'

Table 4. Affirmative participial system in Tundra Nenets

\begin{tabular}{|c|c|c|}
\hline & $\begin{array}{c}\text { Core participants } \\
(\mathrm{S} / \mathrm{A} / \mathrm{P})\end{array}$ & $\begin{array}{c}\text { Non-core participants } \\
(\mathrm{IO}, \mathrm{OBL}, \mathrm{ADV})\end{array}$ \\
\hline Relative past & -mia/-me & $-(o) q m\left({ }^{\prime}\right) a$ \\
\hline Relative present & $-n\left(\right.$ (') $^{\prime} a /-t$ (') $^{\prime} a$ & $-m\left({ }^{\prime}\right) a \&-s^{\prime} \partial /-\partial$ \\
\hline Future/Modal & - mənta & \\
\hline
\end{tabular}

The important thing about the participial systems of this type is that they consist entirely of contextually oriented participles, no matter whether they can relativize the whole range of participants (Northern Khanty), or just a certain subset (Tundra Nenets). As shown, for instance, by Pakendorf (2012), contextually oriented participles are overwhelmingly common throughout Siberia, and may be regarded as one of the features of Siberia as a linguistic area, see also Shagal (2016). Among the languages that exhibit this type of forms are, for instance, Sakha (Turkic), Buryat (Mongolic), Evenki (Tungusic), and Ket (Yeniseic). 


\subsection{Mixed type}

Finally, several languages exhibit a system that is intermediate between those described above. For example, in Komi-Zyryan, there is an inherently oriented active participle in -is', which relativizes all kinds of subjects, cf. (22a) and (22b), and two contextually oriented participles, which can relativize both subjects and non-subjects. The -em form is perfective and rather expresses absolute and relative past events, cf. (22c) and (22d) for subject and locative relativization respectively. The form in -an is mostly used to refer to permanent properties and relative present, cf. example (22e) for subject relativization and (22f) for locative relativization. The participial system of Komi-Zyryan is summarized in Table 5.

(22) Komi-Zyryan, Pechora dialect (Permic, Russia, Brykina and Aralova 2012: 493-498)

a. me bos't-a as-ked-im [terit vo-is'] Saša-ęs

1SG take-NPST REFL-COM-1 yesterday come-PTCP.ACT Sasha-ACC

'I will take Sasha, who came yesterday, with me.'

b. kole duged-ni [Vas'a-es nejt-is'] Pet'a-ẹs is.necessary stop-INF Vasya-ACC beat-PTCP.ACT Petya-ACC

'We need to stop Petya, who is beating Vasya.'

c. [kerka-e pir-ęm] lez' mene jon-a kurtc'c'-i-s house-ILL enter-NMLZ gadfly 1sG.ACC strong-ADV bite-PRT-3

'The gadfly that flew into the house stung me heavily.'

d. [terit sulal-em] mesta-a-s kol'-i-s-ni kok tuj-jas yesterday stand-NMLZ place-INE/ILL-3 remain-PRT-3-PL foot way-PL

'On the place where he was standing yesterday remained some footprints.'

e. sol'-se šsibit-ni $[\boldsymbol{p u}-\boldsymbol{a n}] \quad$ va-e salt-ACC.3 throw-INF boil-DADJ water-ILL

'to throw salt into boiling water'

f. [c'ipan s'ojan pu-an] kastrul'a hen food cook-DADJ saucepan

'the saucepan in which the food for the hens is cooked' 
Table 5. Affirmative participial system in Komi-Zyryan

\begin{tabular}{l|c|c} 
& Subject & Non-Subject \\
\hline Past (relative/absolute) & $-e m /-i s^{\prime}$ & $-e m$ \\
\hline Present (relative/absolute) & $-i s^{\prime}$ & \multirow{2}{*}{-em/-an }
\end{tabular}

A similar situation is observed in Beserman Udmurt, the only difference in orientation being that the form in $-n$ corresponding to the Komi-Zyryan -an cannot relativize subjects. It does, however, occur in a wide range of imperfective relativization contexts, including, for example, direct object relativization, cf. (23a), or instrumental relativization, cf. (23b):

(23) Beserman Udmurt (Permic, Russia, Brykina and Aralova 2012: 511)

a. mânam nâl-e jarat-e mâništem [lẩ̆’on]

1 SG.GEN 1 daughter-1SG love-PRS.3SG 1 SG.GEN2 read-PTCP

kn'iga-m-e

book-1-ACC

'My daughter loves the book that I read to her.'

b. [val-ez š’už’ja-n] sâna-n-z-e Vaš’a ôst-i-z

horse-3 clean-PTCP comb-PTCP-3-ACC Vasya lose-PRT-3

'Vasya lost the comb with which he used to clean the horse.'

In the Mari languages, which also demonstrate a mixed system, there are three participles altogether. Two of them have a relatively free temporal interpretation, the active participle (Meadow Mari -še and Hill Mari $-s ̌ \hat{a})$ can be used to relativize the subject of either transitive or intransitive verb, and the multifunctional participle (Meadow Mari -me and Hill Mari - $m \hat{\partial}$ ) allows the relativization of several lower positions of the Accessibility Hierarchy starting from the direct object. The use of the third participle, which has full contextual orientation, is, on the other hand, restricted to future contexts (Meadow Mari - $\breve{s} a s ̌$ and Hill Mari -šašla $\hat{k} k$ ). The participial system of both Meadow Mari and Hill Mari is summarized in Table 6: 
Table 6. Affirmative participial system in Meadow Mari // Hill Mari

\begin{tabular}{|c|c|c|}
\hline & Subject & Non-Subject \\
\hline Non-Future & $-\check{s} e / /-s ̌ s \hat{\partial}$ & $-m e / /-m \hat{\jmath}$ \\
\hline Future & \multicolumn{2}{|c|}{-šaš // -šašlâkk } \\
\hline
\end{tabular}

Typologically, this type of participial paradigm is fairly uncommon. Nevertheless, a very similar system is observed in Turkish, where the participle in -an relativizes all kinds of subjects, while the choice of the two non-subject participles is determined by whether the situation occurs in the future (-(y)acak) or not (-dik), cf. Pakendorf (2012).

\subsection{Participial systems on the map: Areal tendencies}

As I have shown in the previous sections, participial systems in Uralic languages fall into three major groups, namely languages with inherently oriented participles, languages with contextually oriented participles, and languages featuring a combination of these participial types. What is even more important, however, is that these three types of systems are not randomly distributed across the languages of the family, but rather follow an areal pattern represented on the map in Figure 19.

Languages with inherently oriented participles (North Saami, Finnish, Hungarian and Erzya) are spoken in the western part of the area where the Uralic languages are present. Moreover, the more northern of them, North Saami and Finnish, pattern with other languages of the respective region, such as Russian and Lithuanian, in that they exhibit the active-passive contrast. On the other hand, Hungarian and Erzya make use of absolutive participles, which are typical of the languages of South and Central Europe, for instance, Italian, Macedonian and Greek.

The systems consisting entirely of contextually oriented participles are characteristic of the easternmost Uralic languages, such as Khanty and Tundra Nenets. This is also the dominating type of the North Asia in general, attested in a great number of genealogically diverse languages including Turkic, Tungusic, Mongolic and Yeniseian.

9 The map was designed by Eduard Shagal based primarily on the Linguistic map of the Uralic languages by Maximilian Dörrbecker:

(Chumwa) [CC BY-SA 2.5 (<https://creativecommons.org/licenses/by-sa/2.5>)], available online at: $<$ https://commons.wikimedia.org/wiki/File:Linguistic_map_of_ the_Uralic_languages.png>, accessed on 18.06.2018 via Wikimedia Commons. 


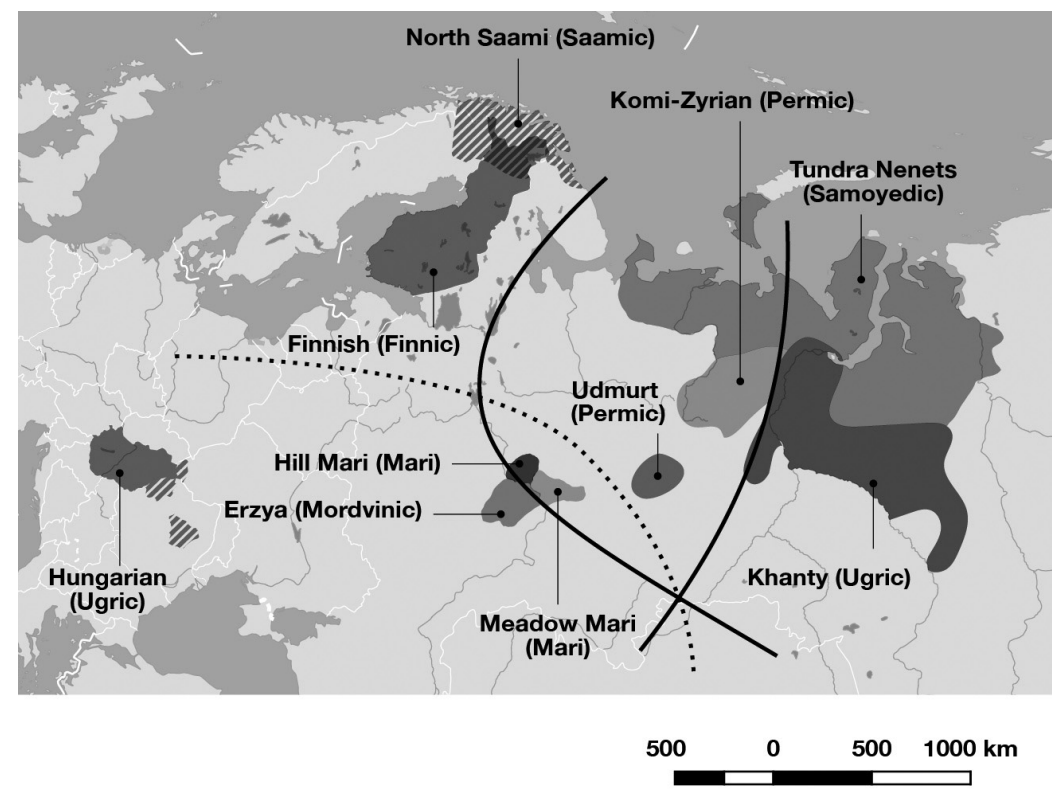

Figure 1. Participial systems in Uralic languages

Languages exhibiting the mixed type (Komi-Zyryan, Udmurt, Meadow Mari and Hill Mari), in which inherently and contextually oriented participles co-exist within the paradigm, are in the middle from the geographical point of view, too. However, this participial system type is hardly an occasional mixture of the two extreme options, but rather seems to reflect, to a certain extent, the contact history of the languages. For instance, the striking synchronic similarity demonstrated by Mari and Turkish in their participial paradigms is most likely a result of the intense long-term contact of Mari with a number of Turkic languages, primarily Chuvash and Tatar, see, for example, KangasmaaMinn (1998: 219). It should be noted though that language contact alone clearly does not suffice to explain the geographical distribution of Uralic participial systems. Thus, for example, as pointed out by the anonymous reviewer, Erzya has experienced a much stronger influence from Turkic than Komi-Zyryan, but it still patterns with Central European languages. Therefore, we should also look for some other factors to provide a full account of the observed areal pattern. 


\section{Negative participles}

Negative participles are not a part of all Uralic participial paradigms. In some languages, such as Erzya or Hungarian, participial relative clauses are symmetrically negated with regular negative particles, which are otherwise used to negate finite predicates and/or nouns and adjectives, cf. an example of an Erzya active participle in (24):

(24) Erzya (Mordvin, Russia, Hamari and Aasmäe 2015: 308)

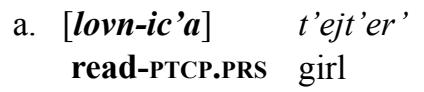

'a girl who reads'

b. [a / avol' lovn-ic'a] t'ejt'er'

NEG / NEG read-PTCP.PRS girl

'a girl who does not read'

In Beserman Udmurt, the $-\check{s}$ ' and $-n$ forms are negated with the negative marker -tem otherwise attaching to regular adjectives, compare $k \hat{s} \hat{s} k$-iš' 'smoking' and $k \hat{s} s ̌ k$-ǐ́s'-tem 'non-smoking', while the $-m$ form receives the specialized marker -te, compare vuza-m 'sold' and vuza-m-te 'unsold' (Brykina and Aralova 2012: 506).

The rest of the languages included in the current sample have specialized negative participial forms. Interestingly, some of them are not even derived directly from any of the affirmative participles, e.g. North Saami -keahtes, or Northern Khanty -li. What is, however, most noteworthy is that even those negative participles that can be traced back to a combination of a particular affirmative form and a negative morpheme, typically exhibit properties that are unique in this language. For example, the Finnish negative participle in -maton is clearly derived from the agentive participial suffix - $m a$ and the nominal negative affix -ton, compare asunto 'apartment' and asunno-ton 'the one without an apartment'. Despite that, the participle has an orientation that is unusual not only for Finnish, but also for European languages in general, namely it is contextually oriented. It can, therefore, be used not only to negate all the active and passive Finnish participles, cf. (25a)-(25c), but also to form negative clauses relativizing peripheral participants of the clause, cf. (25d), and temporal adverbials, cf. (25e): 
(25) Finnish (Finnic, Finland, personal knowledge)

a. [koskaan kuole-maton] rakkaus never die-PTCP.NEG love

'love that never dies'

b. [loppututkinto-a suoritta-maton] hakija final.degree-PART complete-PTCP.NEG applicant

'the applicant that did not complete the final degree'

c. [kenen-kään tietä-mätön] määrä who.GEN-POL know-PTCP.NEG amount 'the amount that nobody knows'

d. [lähes istu-maton] vuodesohva almost sit-PTCP.NEG sofa 'the sofa that almost was not sat on'

e. [täysin sÿ̈-mätön] päivä fully eat-PTCP.NEG day 'the day when (someone) did not eat at all'

A single negative participle is also normally neutralized with respect to TAM properties, since it should be able to negate all the affirmative forms in the language. For instance, as mentioned earlier, in Northern Khanty, the two affirmative participles differ in their tense characteristics, one being used to refer to past and the other to non-past events. The negative participle - $l i$, on the other hand, is neutral with respect to temporal and aspectual characteristics:

(26) Northern Khanty (Ugric, Russia, Nikolaeva 1999: 34)

a. [pe:jal-ti xo:s-li] ńa:wre:m il su:wil-ə-ti swim-INF can-PTCP.NEG child down drown-EP-INF

pit-ว-S

start-EP-PST.3SG

'A child who could not swim started drowning.'

b. [jo:nt-li] je:rnas śuク-na xu:j-ə-l Sew-PTCP.NEG dress corner-LOC lie-EP-NPST.3SG

'A dress which someone did not finish sewing lies in the corner.' 
Interestingly, the Northern Khanty negative participle is also special with respect to its orientation. Although both affirmative participles in the language are contextually oriented, the negative form is only used to negate $\mathrm{S}$ and $\mathrm{P}$ participants, and is, thus, absolutive. This observation made in Nikolaeva (1999) might simply have its roots in the lack of data, but it might also reflect a preference towards absolutive participles in specific contexts. This issue is further accounted for in Shagal (2017: 64).

\section{Conclusions}

Participial paradigms in Uralic languages are primarily based on two main criteria, namely participial orientation (the range of participants that a single participle is able to relativize) and TAM properties. The variation is especially peculiar in the domain of participial orientation. The three groups of languages that can be identified are those employing inherently oriented participles (active, passive and absolutive), those where all the participles are contextually oriented, and those that possess both types of forms.

Importantly, the geographical distribution of different participial systems is not at all random, and areality seems to be the most important factor that could have shaped Uralic participial paradigms. Western Uralic languages (e.g. Finnish and Hungarian), which belong to the Standard Average European linguistic zone, exhibit the contrast between active and passive or absolutive participles exactly in the way that is characteristic of Slavic, Germanic and Baltic varieties. Eastern Uralic varieties (Tundra Nenets and Khanty), which form a linguistic area with other northern Eurasian languages, such as Turkic and Yeniseian, possess participial forms that can be used to relativize a wide range of participants, which is an areal feature in Siberia. This general split between western and eastern Uralic languages reflects their different contact histories on a general level.

On the other hand, there are also features that call for a more detailed explanation in terms of language contact or otherwise. Participial systems of the Permic and Mari languages are typologically uncommon, and demonstrate significant resemblance to some of the Turkic languages. The development of the current participial systems can, therefore, still be a direct result of some kind of language contact (although it is not clear what the exact contacting varieties would be), 
or the two paradigms could have developed independently. The question then would be: what were the triggers for the parallel development of this type of unusual system in two language families?

In general, Uralic participial systems constitute an interesting and challenging case in language contact research and areal linguistics. There is no clear matter borrowing attested in the participial domain, and the languages seem to primarily use native morphological material to derive participial forms (e.g. the old Uralic non-finite *-m formant attested on a vast territory from Finnic to Samoyedic languages). It is, therefore, the pattern that is somehow transmitted via contact. On the other hand, the organization of specific subordinate structures is not a phenomenon that is expected to be easily borrowed, since it is a basic aspect of syntactic organization of a language. This article, thus, provides questions rather than answers in terms of explanations, and unveiling the exact mechanisms underlying the formation of Uralic participial paradigms remains a matter of future studies. Further investigation of the topic can certainly provide valuable insights for the overall typology of participles and help us understand the role of different factors in the development of subordinate structures in general.

\section{Acknowledgements}

I would like to express my gratitude to the numerous native speakers of various Uralic languages who helped me with data collection and verification throughout my work on this paper. I am indebted to Gerson Klumpp, Fedor Rozhanskiy, Jussi Ylikoski, Dmitrii Zelenskii and the anonymous reviewer for their comments on earlier versions of this paper. All shortcomings are of course my own.

\section{Address}

Ksenia Shagal

Department of Languages

P. O. Box 24 (Unioninkatu 40)

00014 University of Helsinki

Finland

E-mail:ksenia.shagal@gmail.com 


\section{References}

Aikhenvald, Alexandra Y. and R. M. W. Dixon (2011) "Non-ergative associations between S and O. In Alexandra Y. Aikhenvald, and R. M. W. Dixon, eds. Language at large: Essays on syntax and semantics, 143-169. Leiden: Brill.

Bartens, Raija (1999) Mordvalaiskielten rakenne ja kehitys. (Mémoires de la Société Finno-Ougrienne, 232.) Helsinki: Suomalais-Ugrilainen Seura.

Brykina, Marija M. and Natal'ja B. Aralova (2012) "Sistemy pričastij v marijskom i permskix jazykax". In Ariadna I. Kuznecova, ed. Finno-ugorskie jazyki: fragmenty grammatičeskogo opisanija. Formal'nyj i funkcional'nyj podxody, 476-520. Moskva: Rukopisnye pamjatniki Drevnej Rusi.

Comrie, Bernard (1981) Language universals and linguistic typology: syntax and morphology. Oxford: Blackwell.

Hamari, Arja and Niina Aasmäe (2015) "Negation in Erzya". In Matti Miestamo, Anne Tamm, and Beáta Wagner-Nagy, eds. Negation in Uralic languages, 293-324. Amsterdam: John Benjamins.

Haspelmath, Martin (1994) "Passive participles across languages". In Barbara Fox and Paul J. Hopper, eds. Voice: form and function, 151-177. (Typological Studies in Language, 27.) Amsterdam: John Benjamins.

Haspelmath, Martin (2001) "The European linguistic area: Standard Average European”. In Martin Haspelmath, Ekkehard König, Wulf Oesterreicher, and Wolfgang Raible, eds. Language typology and language universals, 1492-1510. (Handbücher zur Sprach- und Kommunikationswissenschaft, 20.2.) Berlin: Mouton de Gruyter.

Kangasmaa-Minn, Eeva (1998) “Mari”. In Daniel Abondolo, ed. The Uralic languages, 219-248. London: Routledge.

Kazenin, Konstantin I. (1994) "Split syntactic ergativity: toward an implicational hierarchy”. Sprachtypologie und Universalienforschung 47, 78-98.

Keenan, Edward L., and Bernard Comrie (1977) "Noun phrase accessibility and universal grammar". Linguistic Inquiry 8, 63-99.

Kenesei, István, Robert M. Vago, and Anna Fenyvesi (1998) Hungarian. (Descriptive Grammars.) London: Routledge.

Koptjevskaja-Tamm, Maria (1993) Nominalizations. London: Routledge.

Moravcsik, Edith A. (1978) "On the distribution of ergative and accusative patterns". Lingua 45, 233-279.

Nefedov, Andrey (2012) "Relativization in Ket". In Volker Gast, and Holger Diessel, eds. Clause linkage in cross-linguistic perspective, 191-224. Berlin: Mouton de Gruyter.

Nikolaeva, Irina (1999) Ostyak. (Languages of the World/Materials, 305.) München: Lincom Europa.

Nikolaeva, Irina (2014) A grammar of Tundra Nenets. (Mouton Grammar Library, 65.) Berlin: Mouton de Gruyter.

Pakendorf, Brigitte (2012) "Patterns of relativization in North Asia: towards a refined typology of prenominal participial relative clauses". In Volker Gast and Holger 
Diessel, eds. Clause linkage in cross-linguistic perspective, 253-283. Berlin: Mouton de Gruyter.

Salminen, Tapani (2002) "Problems in the taxonomy of the Uralic languages in the light of modern comparative studies". In Tat'jana B. Agranat and Ol'ga A. Kazakevič, eds. Lingvističeskij bespredel: sbornik statej k 70-letiju A. I. Kuznecovoj, 44-55. Moskva: Izdatel'stvo Moskovskogo universiteta.

Serdobolskaya, Natalia, and Denis Paperno (2006) The polysemy of relativizing and nominalizing markers. Unpublished manuscript. Available online at $<$ http://iling-ran.ru/serdobolskaya/Paperno_Serdobolskaya_NZR-REL.pdf $>$. Accessed on 19.02.2018.

Serdobol'skaja, Natal'ja V., Anfisa A. Il'jevskaja, Sergej A. Minor, Polina S. Miteva, Aleksandra V. Fajnvejc, and Natal'ja S. Matveeva (2012) "Konstrukcii s sentencial'nymi aktantami v finno-ugorskix jazykax". In Ariadna I. Kuznecova, ed. Finno-ugorskie jazyki: Fragmenty grammatičeskogo opisanija. Formal'nyj $i$ funkcional'nyj podxody, 382-475. Moskva: Rukopisnye pamjatniki Drevnej Rusi.

Shagal, Ksenia (2015) “Agenttipartisiipin aikasuhteet: kuinka joustavat ne ovat?” Talk given at the conference XLII Kielitieteen päivät, 21-23 May 2015, Vaasa.

Shagal, Ksenia (2016) "Relative clauses in the languages of Sakhalin as an areal feature". In Ekaterina Gruzdeva and Juha Janhunen, eds. Crosslinguistics and linguistic crossings in Northeast Asia, 153-170. (Studia Orientalia, 117.) Helsinki: Suomen Itämainen Seura.

Shagal, Ksenia (2017) Towards a typology of participles. Helsinki: University of Helsinki.

Shagal, Ksenia and Anna Volkova (to appear) "Participial modification in Hill Mari". Általános Nyelvészeti Tanulmányok.

Shibatani, Masayoshi (2009) "Elements of complex structures, where recursion isn't: the case of relativization”. In T. Givón and Masayoshi Shibatani, eds. Syntactic complexity: diachrony, acquisition, neuro-cognition, evolution, 163-198. (Typological Studies in Language, 85.) Amsterdam: John Benjamins.

Silverstein, Michael (1976) "Hierarchy of features and ergativity". In R. M. W. Dixon, ed. Grammatical categories in Australian languages, 112-171. Canberra: Australian Institute of Aboriginal Studies.

Stassen, Leon (1985) Comparison and Universal Grammar. Oxford: Basil Blackwell.

Toldova, Svetlana Ju., and Natal'ja V. Serdobol'skaja (2002) "Nekotorye osobennosti oformlenija prjamogo dopolnenija v marijskom jazyke”. In Tat'jana B. Agranat, and Ol'ga A. Kazakevič, eds. Lingvističeskij bespredel: sbornik statej k 70-letiju A. I. Kuznecovoj, 106-125. Moskva: Izdatel'stvo Moskovskogo universiteta.

Van Lier, Eva (2009) Parts of speech and dependent clauses: a typological study. (LOT dissertation series, 221.) Utrecht: LOT.

Ylikoski, Jussi (2009) Non-finites in North Saami. (Mémoires de la Société FinnoOugrienne, 257.) Helsinki: Suomalais-Ugrilainen Seura. 


\begin{abstract}
Аннотация. Ксения Шагал: Системы причастий в уральских языках: предварительный обзор. Данная статья представляет собой внутригенетическое типологическое исследование систем причастий в уральской языковой семье, которая отличается заметным разнообразием в этой области. Предлагаемая классификация причастных форм основана на двух основных параметрах: ориентации причастий и их видо-временных характеристиках. Изучаемая выборка включает в себя десять языков. Данные были получены в ходе работы с языковыми описаниями и носителями отдельных языков. Исследование показывает, что системы причастий в уральских языках делятся на три основных типа: системы причастий с внутренней ориентацией, системы причастий с контекстной ориентацией, а также системы, содержащие оба типа причастных форм. В географическом распространении различных систем прослеживаются четкие ареальные тенденции, являющиеся результатом языковых контактов. На протяжении нескольких веков западные уральские языки (например, финский и венгерский) испытывали влияние славянских, германских и балтийских языков, а восточные представители уральской семьи (например, тундровый ненецкий и хантыйский) исторически входят в один языковой ареал с тюркскими и енисейскими языками, распространенными в Сибири. В результате в отношении причастий западные уральские языки можно считать языками среднеевропейского стандарта (Standard Average European), восточные же активно используют преноминальные причастные обороты, характерные для языков Сибири и Дальнего Востока. Примечательно также, что уральские языки не заимствуют сегментного материала для образования причастий, так что рассматриваемая ситуация представляет собой пример заимствования модели (pattern-borrowing), а не формы (matter-borrowing).
\end{abstract}

Ключевые слова: Уральские языки, причастия, относительные предложения, языковые контакты, ареальная лингвистика

\title{
Kokkuvõte. Ksenia Shagal: Ülevaade partitsiibisüsteemidest Uurali
} keeltes. Siinne artikkel on intrageneetiline tüpoloogiline uurimus partitsiibisüsteemidest Uurali keeltes - keelkonnas, mis näitab vastavas domeenis olulist varieeruvust. Partitsiibivormide klassifikatsioon põhineb peamiselt kahel parameetril: partitsiibi orientatsioon või relativiseerimise võimalus ja aegaspekt-modaalsus (tense-aspect-modality, TAM). Valim koosneb kümnest keelest, andmestik pärineb deskriptiivsetest uurimustest kui ka emakeelsetelt kõnelejatelt ja keeleekspertidelt. Uurimusest selgub, et Uurali keelte partitsiibisüsteemid võib jagada kolme peamisesse gruppi: sisemiselt orienteeritud partitsiipidega keeled, kontekstuaalselt orienteeritud partitsiipidega keeled ja nende kahe kombinatsiooni kasutavad keeled. Partitsiibisüsteemide piirkondlik jaotumus näitab tugevaid areaalseid tendentse, mis tulenevad keele- 


\section{Ksenia Shagal}

kontaktidest. Sajandeid on Lääne-Uurali keeled (nt soome ja ungari) olnud mõjutatud slaavi, germaani ja balti keelekujudest, kuid Ida-Uurali keeled (nt tundraneenetsi ja handi) on ajalooliselt moodustanud keelelise areaali PõhjaEuraasia keeltega, nagu turgi ja jenissei. Selle tulemusena kuuluvad partitsiipseid omadusi ilmutavad läänepoolsed keelekujud Euroopa keskmise standardi (Standard Average European, SAE) hulka, idapoolsed keeled aga kasutavad prenominaalseid relatiivlaused, mis on tuntud areaalne joon Põhja-Aasias. On tähelepanuvääre, et Uurali keeltes esinevad partitsiibivormid ei näita selgeid märke vormiainese laenamisest, mis viitab sellele, et kontakti tulemusel kantakse üle pigem struktuurimall.

Märksõnad: Uurali keeled, partitsiibid, relatiivlaused, keelekontakt, areaalne keeleteadus 